\title{
Thiobacillus thiophilus sp. nov., a chemolithoautotrophic, thiosulfate-oxidizing bacterium isolated from contaminated aquifer sediments
}

\author{
Claudia Kellermann and Christian Griebler
}

Correspondence

Christian Griebler

christian.griebler@helmholtz-

muenchen.de

\author{
Helmholtz Center Munich - German Research Center for Environmental Health, Institute of \\ Groundwater Ecology, Ingolstaedter Landstrasse 1, D-85764 Neuherberg, Germany
}

\begin{abstract}
Strain D24TN ${ }^{\top}$ was enriched and isolated from sediment collected from a tar oil-contaminated aquifer at a former gasworks site located in Duesseldorf-Flingern, Germany. Cells of strain $\mathrm{D}_{24} \mathrm{TN}^{\top}$ were rod-shaped, non-spore-forming and stained Gram-negative. Thiosulfate was used as an electron donor. The organism was obligately chemolithoautotrophic and facultatively anaerobic, and grew with either oxygen or nitrate as electron acceptor. Growth was observed at $\mathrm{pH}$ values between 6.3 and 8.7 and at temperatures of -2 to $30{ }^{\circ} \mathrm{C}$; optimum growth occurred at $\mathrm{pH} 7.5-8.3$ and $25-30^{\circ} \mathrm{C}$. The DNA G+C content was $61.5 \mathrm{~mol} \%$. On the basis of the $16 \mathrm{~S}$ rRNA gene sequence analysis, strain D24TN ${ }^{\top}$ clustered in the Betaproteobacteria and was most closely related to Thiobacillus denitrificans (97.6\%) and Thiobacillus thioparus (97.5\%). Based on the phenotypic, chemotaxonomic and phylogenetic data, strain D24TN ${ }^{\top}$ represents a novel species of the genus Thiobacillus, for which the name Thiobacillus thiophilus sp. nov. is proposed. The type strain is $\mathrm{D}_{24 \mathrm{TN}^{\top}}\left(=\mathrm{DSM} 19892^{\top}=\mathrm{JCM} 15047^{\top}\right)$.
\end{abstract}

$\mathrm{CO}_{2}$ fixation is one of the world's most important biogeochemical processes. While the importance of $\mathrm{CO}_{2}$ fixation on the terrestrial surface is known, there is little information about autotrophic processes in the subsurface (Kinkle \& Kane, 2000). Most biogeochemical transformations in groundwater ecosystems are mediated by bacteria and the subsurface complies with all requirements for chemolithoautotrophic processes. At numerous sites electron donors (e.g. $\mathrm{H}_{2}, \mathrm{SO}_{3}^{2-}$ ) and electron acceptors (e.g. $\mathrm{NO}_{3}^{-}, \mathrm{O}_{2}$ ) are available in appropriate combinations and in sufficient amounts together with plenty of inorganic carbon (Labrenz et al., 2005; Madsen \& Ghiorse, 1993). For organic carbon in groundwater ecosystems, two extremes are often met, either pristine systems that are depleted of dissolved organic carbon or polluted aquifers that are overloaded with complex mixtures of organic compounds that can be toxic and can only be degraded by individual micro-organisms (Alfreider et al., 2003). Both situations support the argument that the role of chemolithoautotrophic members of the microbial community is significant.

The GenBank/EMBL/DDBJ accession numbers for the 16S rRNA, $c b b L$ and $c b b M$ gene sequences of strain D24TN ${ }^{\top}$ are EU685841, EU746410 and EU746411, respectively.

Figures showing growth curves of cells of strain D24TN ${ }^{\top}$ under aerobic and anaerobic conditions and consensus phylogenetic trees based on $c b b L$ and $c b b M$ genes are available as supplementary material with the online version of this paper.
It may be the limited availability of dissolved organic carbon in the first case and the necessity to get rid of electrons in the latter case.

In the course of investigating the importance of autotrophic micro-organisms in groundwater ecosystems, we isolated a novel thiosulfate-oxidizing bacterium, designated strain $\mathrm{D} 24 \mathrm{TN}^{\mathrm{T}}$, from sediments of a tar oil-contaminated aquifer under chemolithoautotrophic conditions. Strain $\mathrm{D} 24 \mathrm{TN}^{\mathrm{T}}$ was phylogenetically most closely related to the genus Thiobacillus within the Betaproteobacteria.

Sediments from the quaternary homogeneous sandy aquifer were collected during a well-drilling campaign in June 2005. The aquifer was situated in the area of a former gasworks site in the Rhine valley in Duesseldorf-Flingern, Germany. Here, large amounts of tar oil phase were released into the subsurface during the first half of the 20th century, resulting in a contaminant plume with concentrations of BTEX (benzene, toluene, ethylbenzene and xylenes) of $>100 \mathrm{mg} \mathrm{l}^{-1}$ and polycyclic aromatic hydrocarbons of $>10 \mathrm{mg} \mathrm{l}^{-1}$. Since 1996, most of the oil phases in soil and groundwater have been removed by means of several remediation activities. Residual BTEX concentrations were still at about $20-60 \mathrm{mg} \mathrm{l}^{-1}$ in the plume centre and the average concentrations of polycyclic aromatic hydrocarbons were about $10 \mathrm{mg} \mathrm{l^{-1 }}$. Further details concerning the field site are given by Anneser et al. (2008). 
Strain $\mathrm{D}_{24 \mathrm{TN}^{\mathrm{T}}}$ was isolated from anoxic sediment at $11.2 \mathrm{~m}$ below the soil surface and $4.9 \mathrm{~m}$ below the groundwater table. To protect the samples from contact with oxygen, sediment liners were removed from the borehole under argon and placed in a box flushed with argon gas for further processing. Sediment subsamples were collected using an autoclaved spoon, and transferred immediately to sterile Schott flasks filled with anoxic groundwater from the aquifer and stored at $4{ }^{\circ} \mathrm{C}$ in darkness. Enrichment cultures for chemolithoautotrophic growth were prepared using diluted Widdel freshwater medium (Widdel \& Bak, 1992) (dilution 1:10; pH 7.3, anoxic), with sodium thiosulfate $(10 \mathrm{mM})$ as electron donor and sodium nitrate $(10 \mathrm{mM})$ as electron acceptor. Nitrate (Anneser et al., 2008) as well as thiosulfate (F. Einsiedl, unpublished data) were detected in sufficient amounts in the aquifer. The redox indicator resazurin $\left(1 \mathrm{mg}^{-1}\right)$ was used to confirm anoxic conditions during incubation. Ten grams of sediment (wet wt) was placed into $120 \mathrm{ml}$ serum bottles containing $50 \mathrm{ml}$ enrichment medium. The headspace was replaced by $\mathrm{N}_{2} / \mathrm{CO}_{2}$ gas $(80: 20, \mathrm{v} / \mathrm{v})$ and the bottles were sealed with butyl stoppers (Ochs). Primary enrichment cultures were incubated at $16{ }^{\circ} \mathrm{C}$ (in situ aquifer temperature) in the dark for 3-4 months and transferred to fresh medium when visibly turbid. To isolate the most abundant cell type in the enrichment culture, two dilution series at appropriate dilutions (highest dilution used, $10^{-9}$; enrichment culture cell count was $1.4 \times 10^{8}$ ) were performed under the same culture conditions. To confirm purity, cells of strain D24TN ${ }^{\mathrm{T}}$ were examined using phase-contrast microscopy. Pure cultures were transferred every 2-3 weeks; cell growth was controlled by measuring optical density at $580 \mathrm{~nm}$ $\left(\mathrm{OD}_{580}\right.$; Varian) and occasionally by using microscopic total cell counts. Cell size and shape were determined using transmission electron microscopy. Cells of strain D24TN ${ }^{\mathrm{T}}$ were small rods $(1.8-2.5 \mu \mathrm{m}$ in length and $0.5-0.8 \mu \mathrm{m}$ in diameter) and occurred singly; aggregate formation was not observed (Fig. 1).

Strain D24TN ${ }^{\mathrm{T}}$ grew under oxic conditions. Therefore, the strain was characterized as a facultative anaerobe, exhibiting faster growth in aerobic medium $\left(\mu_{\max }=0.069 \mathrm{~h}^{-1}\right)$ than under anoxic conditions $\left(\mu_{\max }=0.051 \mathrm{~h}^{-1}\right)$. In addition, growth in a more concentrated Widdel medium was tested, i.e. a $1: 2$ dilution was used instead of a $1: 10$ dilution; cells of strain $\mathrm{D} 24 \mathrm{TN}^{\mathrm{T}}$ grew faster in the more concentrated medium $\left(\mu_{\max [\text { Widdel medium } 1: 10]}=0.054 \mathrm{~h}^{-1}\right.$;

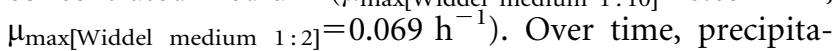
tion of elemental sulfur could be observed (for details see below).

Catalase activity was determined by placing a solution of $3 \%$ hydrogen peroxide on a cell pellet of a freshly grown culture. Oxidase activity was determined using the Fluka oxidase test (Fluka/Sigma Aldrich), according to the manufacturer's instructions. Strain $\mathrm{D} 24 \mathrm{TN}^{\mathrm{T}}$ tested positive for both catalase and oxidase activities.

Unless otherwise described, routine cultivation and growth tests were performed in $120 \mathrm{ml}$ serum bottles containing 50-60 ml Widdel freshwater medium (dilution $1: 2, \mathrm{pH} 7.3$, oxic conditions) with sodium thiosulfate $(10 \mathrm{mM})$ as electron donor and sodium nitrate $(10 \mathrm{mM})$ as electron acceptor, in at least duplicate incubations. Strain D24TN ${ }^{\mathrm{T}}$ did not grow on agar under oxic conditions, either on Widdel freshwater medium containing agar or on nutrient agar plates (meat extract, peptone and agar) or on Thiobacillus denitrificans medium (M832; DSMZ). Growth on agar under anoxic conditions was only observed on medium M832. Strain D24TN ${ }^{\mathrm{T}}$ did not grow on agar plates of Widdel freshwater medium or on nutrient agar.

Cells of strain D24TN ${ }^{\mathrm{T}}$ were Gram-negative; Gram staining was performed using a kit from Sigma-Aldrich, according to the manufacturer's instructions, with Bacillus subtilis and Pseudomonas putida F1 as positive and negative controls, respectively. Spore formation was tested by using pasteurization. Cultures were heated for $10 \mathrm{~min}$ at $80{ }^{\circ} \mathrm{C}$, transferred to fresh medium and incubated at $30{ }^{\circ} \mathrm{C}$ for several weeks. Under these conditions, strain D24TN ${ }^{\mathrm{T}}$ did not form spores.

The $\mathrm{pH}$ range and optimum $\mathrm{pH}$ for growth were determined by using $13 \mathrm{pH}$ values ranging from 6.0 to 8.9 . The initial $\mathrm{pH}$ was achieved using $1 \mathrm{M} \mathrm{HCl}$ or $0.5 \mathrm{M} \mathrm{Na}_{2} \mathrm{CO}_{3}$. As growth of strain $\mathrm{D} 24 \mathrm{TN}^{\mathrm{T}}$ resulted in the $\mathrm{pH}$ of the medium being continuously lowered, the $\mathrm{pH}$ had to be readjusted every 2 days.

Growth occurred between $\mathrm{pH} 6.3$ and 8.7, with an optimum at $\mathrm{pH} 7.5-8.3$. The temperature range for growth was determined at temperatures ranging from -2 to $37{ }^{\circ} \mathrm{C}$. Growth occurred at -2 to $30{ }^{\circ} \mathrm{C}$ (over 1-2 weeks; slower growth occurred at $-2,0$ and $\left.4{ }^{\circ} \mathrm{C}\right)$. The optimum temperature for growth was $25-30{ }^{\circ} \mathrm{C}$. Growth rates related

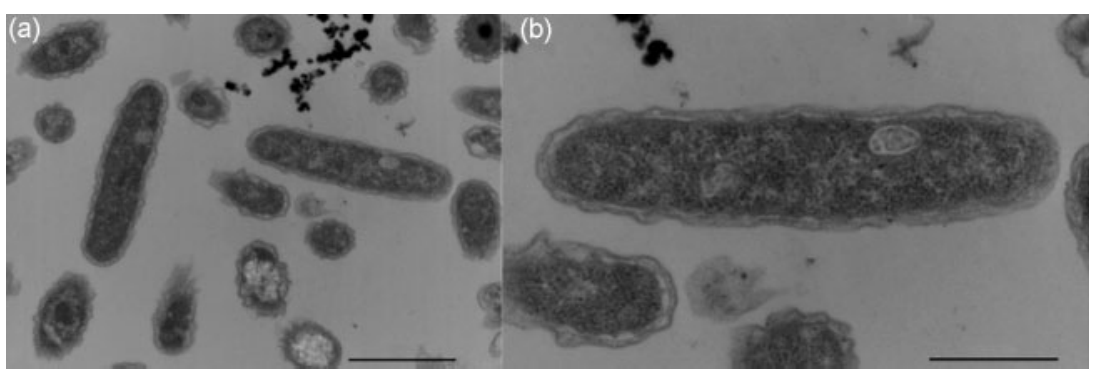

Fig. 1. Transmission electron micrographs of cells of strain D24TN'. (a) Transverse and longitudinal thin sections of several single cells. Bar, $1 \mu \mathrm{m}$. (b) Magnified transverse thin section of a single cell. Bar, $500 \mathrm{~nm}$. 
to various $\mathrm{pH}$ values and temperatures were derived from optical density measurements at $580 \mathrm{~nm}$.

Strain D24TN ${ }^{\mathrm{T}}$ was also tested for its ability to grow with various salt concentrations $(0.5,1,2,3,4,5$ and $8 \% \mathrm{NaCl}$, $\mathrm{w} / \mathrm{v})$. Growth was observed after 2 days incubation with $0.5,1$ and $2 \% \mathrm{NaCl}$; no growth occurred at concentrations of $3 \% \mathrm{NaCl}$ or above.

The ability of strain $\mathrm{D} 24 \mathrm{TN}^{\mathrm{T}}$ to utilize various electron donors was tested by applying $\mathrm{H}_{2}\left(30 \mathrm{ml} \mathrm{H}_{2}\right.$ in headspace of serum bottle), $\mathrm{NH}_{4}^{+}(5 \mathrm{mM}), \mathrm{S}^{2-}(5 \mathrm{mM}), \mathrm{FeS}$ $(3 \mathrm{mM}), \mathrm{S}^{2} \mathrm{O}_{6}^{2-}(10 \mathrm{mM})$ and $\mathrm{S}^{0}\left(0.5 \mathrm{~g} \mathrm{l}^{-1}\right)$ using oxygen and/or nitrate $(5 \mathrm{mM})$ as electron acceptor. Growth occurred with thiosulfate, together with the production of sulfate and small amounts of elemental sulfur, and with tetrathionate as electron donors. Utilization of electron acceptors other than oxygen or nitrate was investigated by testing $\mathrm{SO}_{4}^{2-}(5 \mathrm{mM})$ and $\mathrm{Fe}(\mathrm{III})$ (ferrihydrite $40 \mathrm{mM}$ ). Growth of strain D24TN ${ }^{\mathrm{T}}$ occurred only in medium containing $\mathrm{O}_{2}$ or $\mathrm{NO}_{3}$. Cells grown aerobically completely converted thiosulfate to sulfate (101-103\%) with only trace amounts of elemental sulfur being precipitated whereas, in cells grown aerobically, only $60-75 \%$ of the thiosulfate was converted into sulfate (see Supplementary Fig. S1, available in IJSEM Online) with a significant amount of $S^{0}$ precipitation formed (data not shown). At the same time, part of the nitrate that disappeared during the aerobic incubations appeared as nitrite (32-41\%). In cultures grown in bottles under anaerobic conditions, 69$72 \%$ of the nitrate consumed was converted to nitrite (Supplementary Fig. S1), suggesting that nitrite is an intermediate in total nitrate reduction.

Chemo-organoheterotrophic growth was tested using complex medium (nutrient broth) and Widdel freshwater medium (without thiosulfate as electron source) supplemented with either glucose $(10 \mathrm{mM})$, fructose $(10 \mathrm{mM})$, sodium acetate $(10 \mathrm{mM})$ or formate $(10 \mathrm{mM})$ under oxic conditions.

A similar test series was used to test the capacity of chemolithoheterotrophic growth under oxic conditions with thiosulfate $(10 \mathrm{mM})$ as electron source. Growth was monitored via optical density measurements. In the case of sodium acetate, possible consumption was determined by means of ion chromatography. However, no growth was observed in the absence or presence of thiosulfate; and organic substrates could not be used as an electron or carbon source.

Extraction of genomic DNA from liquid cultures $(50 \mathrm{ml})$ was performed using a modified protocol of Lueders et al. (2004) and Gabor et al. (2003). PCR components (Fermentas) consisted of $5 \mu \mathrm{l} 10 \times$ buffer, $3 \mu \mathrm{l} 25 \mathrm{mM}$ $\mathrm{MgCl}_{2}, \quad 0.5 \mu \mathrm{l}$ each deoxynucleoside triphosphate at $10 \mathrm{mM}, 0.5 \mu \mathrm{l}$ bovine serum albumin $\left(0.25 \mathrm{mg} \mathrm{ml}^{-1}\right)$, $0.5 \mu \mathrm{l}$ each primer at $50 \mu \mathrm{M}$ (MWG), $1 \mu \mathrm{l}$ template DNA, $0.2 \mu \mathrm{l}$ (0.2 units) Taq polymerase and $38.8 \mu \mathrm{l}$ Gibco water (Invitrogen). PCR was performed using an Eppendorf Mastercycler in a total volume of $50 \mu \mathrm{l}$ per reaction.
For amplification of the 16S rRNA gene we used the universal $16 \mathrm{~S}$ primers $27-\mathrm{F}$ ( $5^{\prime}$-AGAGTTTGATCCTGGCTCAG-3') and 1492-R (5'-CGGYTACCTTGTTACGACTT$3^{\prime}$ ) (Weisburg et al., 1991). Cycling parameters were as follows: an initial denaturation for $90 \mathrm{~s}$ at $94{ }^{\circ} \mathrm{C}$ followed by 30 cycles of $30 \mathrm{~s}$ at $94{ }^{\circ} \mathrm{C}, 30 \mathrm{~s}$ at $52{ }^{\circ} \mathrm{C}$ and $90 \mathrm{~s}$ at $70{ }^{\circ} \mathrm{C}$, and extension for $5 \mathrm{~min}$ at $70{ }^{\circ} \mathrm{C}$. Amplification products were analysed on a $2 \%$ agarose gel to ensure the correct size (16S rRNA $1.4 \mathrm{~kb}$ ).

The PCR products were purified using a MinElute PCR Purification kit (Qiagen) according to the manufacturer's instructions. For direct sequencing, a Big Dye Terminator labelling kit (Applera Norwalk) with an ABI PRISM 3730 DNA analyzer (Applied Biosystems) was used.

Sequence data were analysed with the ARB software package (Ludwig et al., 2004). Phylogenetic trees were calculated by using maximum-likelihood (Olsen et al., 1994) and neighbour-joining (Saitou \& Nei, 1987) analyses. According to the phylogenetic analysis of the 16S rRNA gene sequence, strain $\mathrm{D} 24 \mathrm{TN}^{\mathrm{T}}$ was closely affiliated with the genus Thiobacillus (Fig. 2), with the closest relative being T. denitrificans ( $97.6 \%$ sequence similarity).

As the Calvin cycle is the most prominent $\mathrm{CO}_{2}$ fixation pathway in aerobes and facultative anaerobes and, because of the close relatedness to T. denitrificans, strain D24TN ${ }^{\mathrm{T}}$ was tested for the corresponding marker genes, i.e. the $c b b$ genes, encoding ribulose 1,5-bisphosphate carboxylase/ oxygenase (RuBisCO), the key enzymes of the Calvin cycle.

The primer sets for Form I RuBisCO ( $c b b L G$ and $c b b L \mathrm{R}) \quad c b b L G 1-\mathrm{F}$ (5'-GGCAACGTGTTCGGSTTCAA-3') and $c b b L G 1-G$ (5'-TTGATCTCTTTCCACGTTTCC-3'), cbbLR1-F (5'-AAGGAYGACGAGAACATC- $\left.{ }^{\prime}\right)$ and cbbLR1-R (5'-TCGGTCGGSGTGTAGTTGAA-3') (Selesi et al., 2005) and the primer set for Form II RuBisCO $(c b b M) \quad c b b M$-f (5'-GGCACCATCATCAAGCCCAAG-3') and $c b b M-\mathrm{r}$ (5'-TCTTGCCGTAGCCCATGGTGC-3') (Alfreider et al., 2003) were used to amplify the RuBisCO genes, with the following cycling parameters: an initial denaturation for $4 \mathrm{~min}$ at $94{ }^{\circ} \mathrm{C}$ followed by 32 cycles of $1 \mathrm{~min}$ at $94{ }^{\circ} \mathrm{C}, 1 \mathrm{~min}$ at $62{ }^{\circ} \mathrm{C}(c b b L \mathrm{G})$ or $57^{\circ} \mathrm{C}(c b b M$ and $c b b L \mathrm{R})$ and $1 \mathrm{~min}$ at $70{ }^{\circ} \mathrm{C}$, ending with a $10 \mathrm{~min}$ extension at $70{ }^{\circ} \mathrm{C}$.

Amplification products were analysed on a $2 \%$ agarose gel to ensure correct size ( $c b b L \mathrm{G} 1.1 \mathrm{kp}, c b b L \mathrm{R} 0.8 \mathrm{~kb}, c b b M$ $0.5 \mathrm{~kb}$ ). PCR products were processed for sequencing as described above for the 16S PCR product. Sequence data were analysed with the ARB software package (Ludwig et al., 2004), as described above. Phylogenetic trees were calculated by using maximum-likelihood (Olsen et al., 1994) and neighbour-joining (Saitou \& Nei, 1987) analyses. Strain D24TN ${ }^{\mathrm{T}}$ was positive for $c b b L$ type green-like (GenBank no. EU746410) and $c b b M$ (EU746411) genes, therefore possessing the potential to fix $\mathrm{CO}_{2}$ via the Calvin cycle (see Supplementary Figs S2 and S3, available in IJSEM Online). The strain was negative for $c b b L$ type red-like 


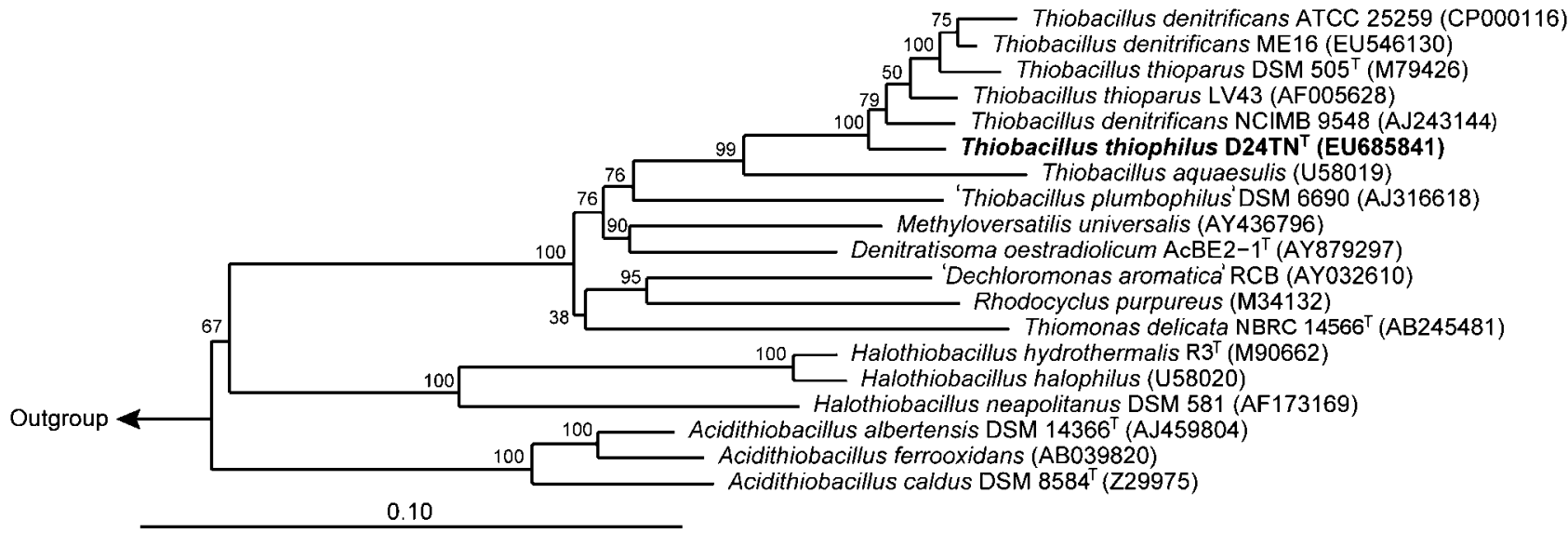

Fig. 2. Neighbour-joining phylogenetic tree based on $16 \mathrm{~S}$ rRNA gene sequences showing the positions of strain $D_{24 T N^{\top}}$ (Thiobacillus thiophilus sp. nov.) and some other related taxa. Bootstrap values (percentages of 1000 resamplings) are given at branch points. Bar, $10 \%$ estimated sequence divergence.

genes. Sequence similarities to $c b b L G$ sequences of Thiobacillus thioparus (DQ390449) and T. denitrificans (L42940) were 91.9 and $88.1 \%$, respectively, and similarities to $c b b M$ sequences of T. thioparus (EU746412) and T. denitrificans (NC007404; L37437) were $88.4 \%$ for each.
To confirm that strain $\mathrm{D} 24 \mathrm{TN}^{\mathrm{T}}$ used the Calvin cycle for $\mathrm{CO}_{2}$ fixation, RT-PCR was used to detect transcription of the $c b b$ genes. For isolation of the total RNA, $50 \mathrm{ml}$ dense cultures, grown aerobically and anaerobically, were centrifuged (4000 r.p.m., 15 min; Megafuge1.0R, Heraeus).

Table 1. Characteristics that differentiate strain $\mathrm{D} 24 \mathrm{TN}^{\top}$ (Thiobacillus thiophilus sp. nov.) from its closest relatives $T$. denitrificans and $T$. thioparus

All taxa are oxidase positive and grow on or oxidize thiosulfate. All taxa are positive for tetrathionate and all are negative for chemo-organotrophic growth (data for $T$. thioparus and T. denitrificans are from Kelly \& Wood, 2000). ND, No data.

\begin{tabular}{|c|c|c|c|}
\hline Characteristic & Strain D24TN ${ }^{\mathrm{T}}$ & T. thioparus & T. denitrificans \\
\hline Morphology & Rods & Short rods & Rods \\
\hline Cell length $(\mu \mathrm{m})$ & $1.8-2.5$ & $1.0-2.0$ & $1.0-3.0^{*}$ \\
\hline Relation to $\mathrm{O}_{2}$ & Facultative anaerobe & Aerobe $^{*}$ & Facultative anaerobe ${ }^{\star}$ \\
\hline Sporulation & - & - & ND \\
\hline Temperature optimum $\left({ }^{\circ} \mathrm{C}\right)$ & $25-30$ & $25-30 \dagger$ & $28-32^{*}$ \\
\hline Temperature range for growth $\left({ }^{\circ} \mathrm{C}\right)$ & -2 to 30 & ND & ND \\
\hline pH optimum & $7.5-8.3$ & $6.0-8.0 \dagger$ & $6.8-7.4^{*}$ \\
\hline $\mathrm{pH}$ range for growth & $6.3-8.7$ & $5.0-9.0 \ddagger$ & ND \\
\hline Catalase & + & ND & + \\
\hline \multicolumn{4}{|l|}{ Growth on/oxidation of: } \\
\hline Hydrogen & - & ND & ND \\
\hline Sulfur & - & $-末$ & $+^{*}$ \\
\hline Ammonium & - & ND & ND \\
\hline Sulfide & - & $+\ddagger$ & $+^{*}$ \\
\hline $\mathrm{FeS}$ & - & $\mathrm{ND}$ & $+\S$ \\
\hline Thiocyanate & - & $+^{*}$ & $+^{*}$ \\
\hline DNA G $+\mathrm{C}$ content $(\mathrm{mol} \%)$ & 61.5 & $61.0-66.0 \dagger$ & $63.0-68.0 \dagger$ \\
\hline $\begin{array}{l}\text { 16S rRNA sequence similarity with strain } \\
\text { D24TN }{ }^{\mathrm{T}}(\%)\end{array}$ & $(100)$ & 97.5 & 97.6 \\
\hline
\end{tabular}

${ }^{\star}$ Data from Kelly \& Wood (2000).

$\dagger$ Data from Robertson \& Kuenen (2006).

$\$$ Data from Vlasceanu et al. (1997).

§Data from Beller et al. (2006). 
Further preparation was performed as described by Schmitt et al. (1990).

To obtain pure RNA without DNA, $25 \mu \mathrm{l}$ DNA/RNA extracts were digested with DNase I (20 U; Fermentas) at $37{ }^{\circ} \mathrm{C}$ for $45 \mathrm{~min}$.

An AccessQuick RT-PCR system (Promega) was used to monitor the transcription of RuBisCO Form I and II genes using the same primers as described above. Reactions were carried out in $50 \mu \mathrm{l}$ volumes, according to the manufacturer's instructions. RT-PCR parameters were $30 \mathrm{~min}$ at $45{ }^{\circ} \mathrm{C}$ and $5 \mathrm{~min}$ at $95{ }^{\circ} \mathrm{C}$, followed by 30 cycles of $30 \mathrm{~s}$ at $95{ }^{\circ} \mathrm{C}, 30 \mathrm{~s}$ at 57 and $62{ }^{\circ} \mathrm{C}$ (depending on the specific primer pair), and $1 \mathrm{~min}$ at $68{ }^{\circ} \mathrm{C}$, followed by 1 cycle of 5 min at $68{ }^{\circ} \mathrm{C}$. Amplification products were separated on $2 \%$ agarose gels in $1 \times$ TAE buffer $(0.04 \mathrm{M}$ Tris/acetate; $0.001 \mathrm{M}$ EDTA), stained with ethidium bromide and visualized under UV light. For each RT-PCR, a negative control PCR without avian myeloblastosis virus reverse transcriptase was performed to rule out DNA contamination. Cells grown aerobically and anaerobically were shown to transcribe $c b b M$ and green-like $c b b L$ genes.

In addition, enzyme activity tests were performed, to determine RuBisCO activity in cell extracts of aerobically grown cells of strain D24TN ${ }^{\mathrm{T}}$ as well as in extracts of anaerobically grown cells. The enzyme assays were performed as described by Hügler et al. (2003). RuBisCO activity was detected in aerobically as well as in anaerobically grown cells of D24TN ${ }^{\mathrm{T}}$ (data not shown).

Determination of the $\mathrm{G}+\mathrm{C}$ content of the DNA was performed at the DSMZ. The content was calculated from the ratio of deoxyguanosine (dG) and thymidine (dT), according to the method described by Mesbah et al. (1989), by means of HPLC analysis (Shimadzu Corporation). The $\mathrm{G}+\mathrm{C}$ content of the DNA of strain D24TN ${ }^{\mathrm{T}}$ was $61.5 \%$.

To determine the genomic relatedness between strain $\mathrm{D} 24 \mathrm{TN}^{\mathrm{T}}$ and its closest relative T. denitrificans, DNA-DNA hybridization was performed. For each of the two species, $3 \mathrm{~g}$ cell material was centrifuged and resuspended $1: 1(\mathrm{v} / \mathrm{v})$ in 2propanol/MilliQ ultrapure water (Millipore). All other steps were carried out at the DSMZ as described by Huß et al. (1983) and De Ley et al. (1970), with the modifications of Cashion et al. (1977). Based on 16S rRNA gene sequence analysis, strain $\mathrm{D} 24 \mathrm{TN}^{\mathrm{T}}$ belongs to the class Betaproteobacteria. According to Wayne et al. (1987), strains with DNADNA relatedness values greater than $70 \%$ belong to the same species. DNA-DNA hybridization analysis between strain $\mathrm{D} 24 \mathrm{TN}^{\mathrm{T}}$ and $T$. denitrificans resulted in a relatedness value of $24.8 \%$; therefore strain $\mathrm{D} 24 \mathrm{TN}^{\mathrm{T}}$ is clearly distinct from $T$. denitrificans (Table 1). Therefore, strain $\mathrm{D} 24 \mathrm{TN}^{\mathrm{T}}$ represents a novel species of the genus Thiobacillus, for which the name Thiobacillus thiophilus sp. nov. is proposed.

\section{Description of Thiobacillus thiophilus sp. nov.}

Thiobacillus thiophilus (thi.o' phi.lus. Gr. n. thion sulfur; Gr. adj. philos loving; N.L. masc. adj. thiophilus sulfur-loving).
Cells are Gram-negative, small rods $(1.8-2.5 \mu \mathrm{m}$ in length and $0.5-0.8 \mu \mathrm{m}$ in diameter) that can grow aerobically and anaerobically. Oxidase- and catalase-positive. Does not grow aerobically on agar plates; anaerobically grown colonies are circular, smooth, shiny, convex and yellow in colour with a lighter-coloured fringe after 14 days incubation. Spores are not produced and aggregates are not formed. Growth occurs anaerobically as a chemolithoautotroph on thiosulfate, with nitrate as the final electron acceptor. Also grows as an aerobic chemolithoautotroph on thiosulfate. Heterotrophic growth is not observed. Temperature range for growth is -2 to $30{ }^{\circ} \mathrm{C}$, with optimum growth at $25-30{ }^{\circ} \mathrm{C}$. $\mathrm{pH}$ range for growth is 6.3-8.7, with optimum growth at $\mathrm{pH}$ 7.5-8.3. Growth occurs under saline conditions to an upper $\mathrm{NaCl}$ concentration of $2 \%(\mathrm{w} / \mathrm{v})$.

The type strain, D24TN ${ }^{\mathrm{T}}\left(=\mathrm{DSM} 19892^{\mathrm{T}}=\mathrm{JCM} 15047^{\mathrm{T}}\right)$, was isolated from sediment derived from a tar oilcontaminated aquifer. Strain D24TN ${ }^{\mathrm{T}}$ is obligately chemolithoautotrophic, oxidizes thiosulfate and has a DNA G + C content of $61.5 \mathrm{~mol} \%$ (HPLC).

\section{Acknowledgements}

This project was supported by the Helmholtz Zentrum München. We thank the people from the Stadtwerke Duesseldorf (i.e. L. Richters) for sample access, B. Anneser for help during sample collection and M. Huegler for help with the enzyme activity measurements. We further thank A. Hartmann, R. U. Meckenstock and D. Selesi for continuous support.

\section{References}

Alfreider, A., Vogt, C., Hoffmann, D. \& Babel, W. (2003). Diversity of ribulose-1,5-bisphosphate carboxylase/oxygenase large-subunit genes from groundwater and aquifer microorganisms. Microb Ecol 45, 317-328.

Anneser, B., Einsiedl, F., Meckenstock, R. U., Richters, L., Wisotzky, F. \& Griebler, C. (2008). High-resolution monitoring of biogeochemical gradients in a tar oil-contaminated aquifer. Appl Geochem 23, 1715-1730.

Beller, H. R., Chain, P. S. G., Letain, T. E., Chakicherla, A., Larimer, F. W., Richardson, P. M., Coleman, M. A., Wood, A. P. \& Kelly, D. P. (2006). The genome sequence of the obligately chemolithoautotrophic, facultatively anaerobic bacterium Thiobacillus denitrificans. J Bacteriol 188, 1473-1488.

Cashion, P., Holder-Franklin, M. A., McCully, J. \& Franklin, M. (1977). A rapid method for the base ratio determination of bacterial DNA. Anal Biochem 81, 461-466.

De Ley, J., Cattoir, H. \& Reynaerts, A. (1970). The quantitative measurement of DNA hybridization from renaturation rates. Eur $J$ Biochem 12, 133-142.

Gabor, E., de Vries, E. \& Janssen, D. (2003). Efficient recovery of environmental DNA for expression cloning by indirect extraction methods. FEMS Microbiol Ecol 44, 153-163.

Hügler, M., Huber, H., Stetter, K. O. \& Fuchs, G. (2003). Autotrophic $\mathrm{CO}_{2}$ fixation pathways in archaea (Crenarchaeota). Arch Microbiol 179, 160-173.

Huß, V. A. R., Festl, H. \& Schleifer, K. H. (1983). Studies on the spectrophotometric determination of DNA hybridization from renaturation rates. Syst Appl Microbiol 4, 184-192. 
Kelly, D. P. \& Wood, A. P. (2000). Confirmation of Thiobacillus denitrificans as a species of the genus Thiobacillus, in the $\beta$-subclass of the Proteobacteria, with strain NCIMB 9548 as the type strain. Int J Syst Evol Microbiol 50, 547-550.

Kinkle, B. K. \& Kane, T. C. (2000). Chemolithoautotrophic microorganisms and their potential role in subsurface environments. In Ecosystems of the World, pp. 309-318. Edited by H. Wilkens, D. C. Culven \& W. F. Humphreys. Amsterdam: Elsevier.

Labrenz, M., Jost, G., Pohl, C., Beckmann, S., Martens-Habbena, W. \& Jurgens, K. (2005). Impact of different in vitro electron donor/acceptor conditions on potential chemolithoautotrophic communities from marine pelagic redoxclines. Appl Environ Microbiol 71, 6664-6672.

Ludwig, W., Strunk, O., Westram, R., Richter, L., Meier, H., Yadhukumar, Buchner, A., Lai, T., Steppi, S. \& other authors (2004). ARB: a software environment for sequence data. Nucleic Acids Res 32, 1363-1371.

Lueders, T., Manefield, M. \& Friedrich, M. W. (2004). Enhanced sensitivity of DNA- and rRNA-based stable isotope probing by fractionation and quantitative analysis of isopycnic centrifugation gradients. Environ Microbiol 6, 73-78.

Madsen, E. \& Ghiorse, W. C. (1993). Groundwater microbiology: subsurface ecosystem processes. In Aquatic Microbiology: an Ecological Approach, pp. 167-213. Edited by T. E. Ford. Boston: Blackwell Scientific Publications.

Mesbah, M., Premachandran, U. \& Whitman, W. B. (1989). Precise measurement of the $\mathrm{G}+\mathrm{C}$ content of deoxyribonucleic acid by highperformance liquid chromatography. Int J Syst Bacteriol 39, 159-167.

Olsen, G. J., Matsuda, H., Hagstrom, R. \& Overbeek, R. (1994). fastDNAml: a tool for construction of phylogenetic trees of DNA sequences using maximum likelihood. Comput Appl Biosci 10, 41-48.
Robertson, L. A. \& Kuenen, J. G. (2006). The Genus Thiobacillus. In The Prokaryotes, pp. 812-827. Edited by M. Dworkin, S. Falkow, E. Rosenberg, K. H. Schleifer \& E. Stackebrandt. Berlin: Springer.

Saitou, N. \& Nei, M. (1987). The neighbor-joining method: a new method for reconstructing phylogenetic trees. Mol Biol Evol 4, 406-425.

Schmitt, M. E., Brown, T. \& Trumpower, B. (1990). A rapid and simple method for preparation of RNA from Saccharomyces cerevisia. Nucleic Acids Res 18, 3091-3092.

Selesi, D., Schmid, M. \& Hartmann, A. (2005). Diversity of green-like and red-like ribulose-1,5-bisphosphate carboxylase/oxygenase largesubunit genes $(c b b L)$ in differently managed agricultural soils. Appl Environ Microbiol 71, 175-184.

Vlasceanu, L., Popa, R. \& Kinkle, B. K. (1997). Characterization of Thiobacillus thioparus LV43 and its distribution in a chemoautotrophically based groundwater ecosystem. Appl Environ Microbiol 63, 3123-3127.

Wayne, L., Brenner, D. J., Colwell, R. R., Grimont, P. A. D., Kandler, O., Krichevsky, M. I., Moore, L. H., Moore, W. E. C., Murray, R. G. E. \& other authors (1987). International Committee on Systematic Bacteriology. Report of the ad hoc committee on reconciliation of approaches to bacterial systematics. Int J Syst Bacteriol 37, 463-464.

Weisburg, W. G., Barns, S. M., Pelletier, D. A. \& Lane, D. J. (1991). 16 S ribosomal DNA amplification for phylogenetic study. J Bacteriol 173, 697-703.

Widdel, F. \& Bak, F. (1992). Gram-negative mesophilic sulfatereducing bacteria. In The Prokaryotes, pp. 3352-3378. Edited by A. Balows, H. G. Trüper, M. Dworkin, W. Harder \& K. H. Schleifer. New York: Springer. 